\title{
Comparison of bench-top simulation versus traditional training models in diagnostic arthroscopic skills training
}

\author{
Diyagnostik artroskopik beceriler eğitiminde masa başı simülasyonu ile \\ geleneksel eğitim modellerinin karşılaştırılması
}

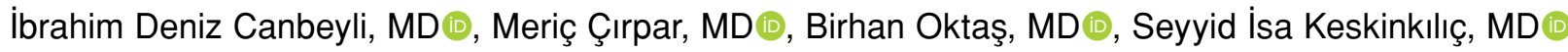 \\ Department of Orthopedics and Traumatology, Kırıkkale University, School of Medicine, Kırıkkale, Turkey
}

\begin{abstract}
Objectives: This study aims to compare the efficacy of existing training models for acquisition of arthroscopic skills and to investigate the most effective training method or combination of methods for residents.

Materials and methods: A total of 100 fifth-year students from medical school (40 males, 60 females; mean age 23.7 years; range, 22 to 33 years) volunteered to participate in the study and were randomly divided into five education groups (E1-5): group E1 (trained on bench-top simulator), group E2 (read surgical technique), group E3 (read surgical technique and watched surgical video), group E4 (watched surgical video only), and group E5 (control group). After completion of the pre-training, each student was individually asked to perform an arthroscopy practice. A checklist containing the tasks to be performed was given to students and students were asked to complete the tasks on the checklist in five minutes.
\end{abstract}

Results: In group E1, the mean rate of successful achievement of tasks was significantly higher than other groups in both knee and shoulder arthroscopy models. Rate of each task was statistically similar for groups E2, E3, E4 and E5. In group E1, mean durations for completion of tasks in both arthroscopy models were significantly shorter than other groups. There was no statistically significant difference in terms of gender between those who successfully completed the tasks in both arthroscopy models.

Conclusion: A basic arthroscopic bench-top simulator may be a low-cost and effective training method to increase arthroscopic skill levels in resident training compared to traditional methods.

Keywords: Arthroscopic simulator; low-cost arthroscopic skills laboratory; surgical training; residents training.

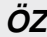

Amaç: $\mathrm{Bu}$ çalışmada, artroskopik becerilerin kazanımı için mevcut eğitim modellerinin etkinliği karşılaştırıldı ve asistanlar için en etkili eğitim yöntemi veya yöntemler kombinasyonu araştırıldı.

Gereç ve yöntemler: Tıp fakültesinden toplam 100 beşinci sınıf öğrencisi (40 erkek, 60 kadın; ort. yaş 23.7 yıl; dağılım, 22-33 y1l) çalışmaya katılmaya gönüllü oldu ve randomize olarak beş eğitim grubuna ayrıldı (E1-5): grup E1 (masa başı simülatör üzerinde eğitim aldı), grup E2 (cerrahi tekniği okudu), grup E3 (cerrahi tekniği okudu ve cerrahi video izledi), grup E4 (sadece cerrahi video izledi) ve grup E5 (kontrol grubu). Ön eğitimin tamamlanmasının ardından, her öğrenciden bireysel olarak bir artroskopi uygulaması yapması istendi. Yapılması gereken görevleri içeren bir kontrol listesi öğrencilere verildi ve öğrencilerden listedeki görevleri beş dakika içerisinde tamamlamaları istendi.

Bulgular: Grup E1'de, görevleri başarıyla tamamlamanın ortalama oranları hem diz hem artroskopi modellerinde diğer gruplardan anlamlı olarak daha yüksek idi. Grup E2, E3, E4 ve E5 için her bir görevin oranı istatistiksel olarak benzer idi. Grup åEl'de, her iki artroskopi modelindeki görevleri tamamlamanın ortalama süreleri diğer gruplardan anlamlı olarak daha kısa idi. Her iki artroskopi modelinde görevleri başarıyla tamamlayanlar arasında cinsiyet açısından istatistiksel olarak anlamlı bir farklılık yoktu.

Sonuç: Asistan eğitiminde artroskopik beceri düzeylerini artırmak için geleneksel yöntemlere göre temel bir artroskopik masa başı simülatörü düşük maliyetli ve etkili bir eğitim yöntemi olabilir.

Anahtar sözcükler: Artroskopik simülatör; düşük maliyetli artroskopik beceriler laboratuvarı; cerrahi eğitim; asistan eğitimi.

Received: April 25, 2018 Accepted: June 05, 2018

Correspondence: İbrahim Deniz Canbeyli, MD. Kırıkkale Üniversitesi Tıp Fakültesi Ortopedi ve Travmatoloji Anabilim Dalı, 71450 Yahşihan, Kırıkkale, Turkey. Tel: +90 532 - 2214147 e-mail: denizcanbeyli@gmail.com 
Mastery of any surgical technique can be gained through the development of skill areas including communication skills, patient evaluation, decision making abilities, and technical knowledge and competence..$^{[1,2]}$ Although all these areas are important, acquisition of technical knowledge and competence is the primary component of surgical training.

For decades, traditional surgical training consisted of the supervision of a senior surgeon in the operating room (OR), supported by printed and audio-visual documents. However, this approach is being gradually abandoned around the world due to its inherent drawbacks. These drawbacks are the cost of training, ${ }^{[3]}$ increased operative time, ${ }^{[4]}$ increased patient morbidity, ${ }^{[4]}$ and ethical issues. In addition, for endoscopic surgery, it is well-documented that less invasive surgical interventions are technically more demanding, so it is more difficult for learners to acquire skills through observing and assisting in the OR. ${ }^{[5,6]}$ This is particularly true for arthroscopic surgery, which requires high-level of psychomotor skills to manipulate tools in a narrow three-dimensional space with the guidance of a two-dimensional image. Thus, technical surgical skills training outside the OR is now more important for surgery residents, and it is becoming a prerequisite for performing surgical interventions. ${ }^{[7]}$

A variety of training models outside the OR have been introduced for arthroscopic skills training, and these can be applied alone or in combination. Simulation training involves practicing on arthroscopy models, with or without computerized systems, with conceptual support from both printed and audiovisual documents; such training has recently become the mainstay of arthroscopic surgery training. The efficacy of this training model is well-described, ${ }^{[7-9]}$ and it is reported to be more cost-effective than training methods that involve OR experience. ${ }^{[10]}$ However, computerized simulation systems have the drawbacks of being expensive and challenging to obtain particularly in developing countries. Thus, original out-of-use arthroscopy systems can be used on joint models that usually have acceptable cost when compared with complex computerized systems.

It is hypothesized that practicing with out-of-use standard arthroscopy systems on joint models can be an effective alternative to modern computerized simulation systems, particularly in developing countries where many surgical training centers may not have access to modern simulation systems.

In this study, current out-of-OR arthroscopic training methods were compared with arthroscopic simple knee and shoulder bench-top simulators used with out-of-use arthroscopy towers. Therefore, in this study, we aimed to compare the efficacy of existing training models for acquisition of arthroscopic skills and to investigate the most effective training method or combination of methods for residents.

\section{MATERIALS AND METHODS}

This study was conducted between December 2016 and December 2017 in the Skills Practice Laboratory of the Department of Orthopedics and Traumatology at our institution. A total of 100 fifth-year students from medical school (40 males, 60 females; mean age 23.7 years; range, 22 to 33 years) volunteered to participate. None of the students had ever seen a live arthroscopic surgery or video thereof. Students who had watched videos of endoscopic, laparoscopic, thoracoscopic, or ureteroscopic surgery were excluded. Students who had watched surgical videos or read surgical techniques about arthroscopy or endoscopic, laparoscopic, thoracoscopic, or ureteroscopic surgery surgical interventions were also excluded. The study protocol was approved by the Kırıkkale University Hospital Ethics Committee. A written informed consent was obtained from each participant. The study was conducted in accordance with the principles of the Declaration of Helsinki.

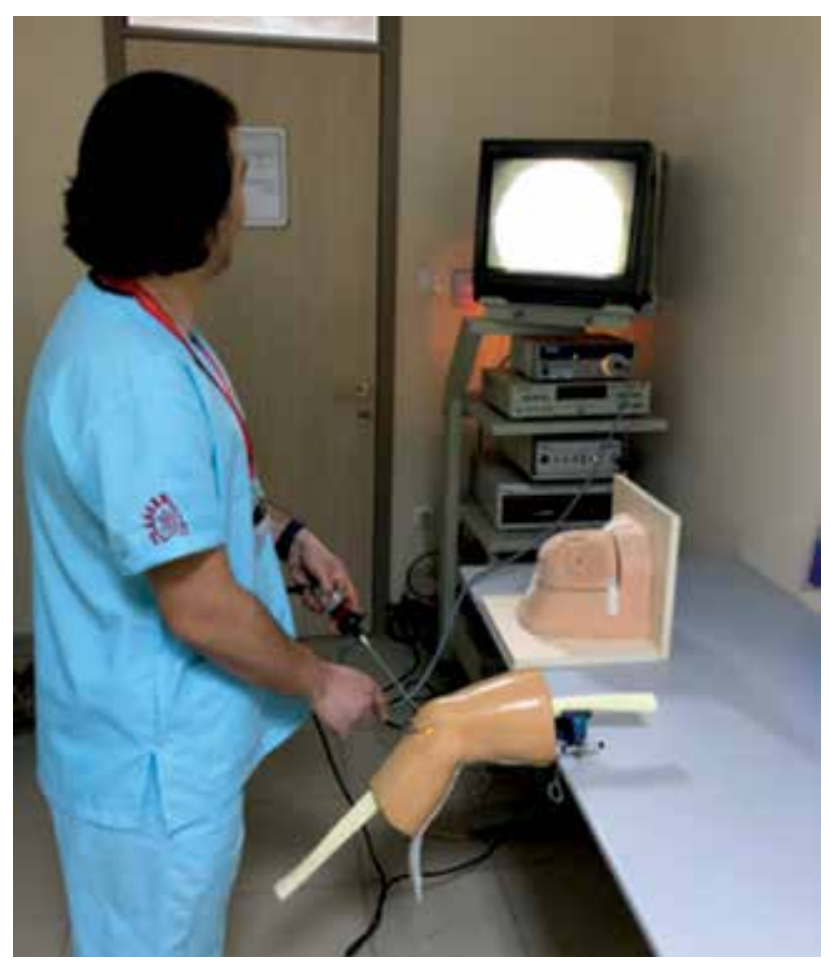

Figure 1. Out-of-use arthroscopy tower used for training students and evaluating arthroscopy tasks. 
TABLE I

Diagnostic knee arthroscopy checklist for performed tasks sorted sequentially

\begin{tabular}{l} 
Scope introduction \\
Introduce scope into lateral compartment $\left(T_{1}\right)$ \\
Redirect scope into patellofemoral compartment $\left(T_{2}\right)$ \\
Diagnostic knee arthroscopy \\
Introduce probe to medial compartment $\left(T_{3}\right)$ \\
Probe the anterior horn of the medial meniscus $\left(T_{4}\right)$ \\
View medial gutter $\left(T_{5}\right)$ \\
View the intercondylar notch $\left(T_{6}\right)$ \\
Probe anterior cruciate ligament $\left(T_{7}\right)$ \\
View lateral gutter $\left(T_{8}\right)$ \\
Probe lateral meniscus $\left(T_{9}\right)$ \\
\hline T: Task.
\end{tabular}

Students included in the study were randomly divided into five education groups (E1-5) each consisting 20 students, using the online research randomizer at the site www.randomizer.org. An old, out-of-use arthroscopic tower was used to make a basic, low-cost arthroscopic simulator system (Figure 1). All students in each group were allowed to continue studying using the training model assigned to their group until they thought they were ready for successfully performing tasks of their group.

For knee arthroscopy, in addition to localization of arthroscopy portals and manipulation of the arthroscope and probe, the knee training model (KD-01 Sel Bones, Kayseri, Turkey) introduced access to lateral, medial, and patellofemoral compartments; visualization of medial and lateral gutters and intercondylar notch; and probing of both menisci and anterior cruciate ligament. For shoulder arthroscopy, anatomic landmarks of the shoulder region and portals for access to the glenohumeral joint were shown on the Alex shoulder model (Sawbones Vashon, WA, USA). After visualization of the joint space, the faculty used the shoulder model to show students the procedure for probing of the articular cartilage on both humeral head and glenoid; superior, anterior, and posterior labrum; and retraction of the biceps tendon into the joint space on shoulder model.

The main aspects of knee and shoulder arthroscopy were initially demonstrated by a faculty expert on an arthroscopic simulator for group E1. Group E2 watched a surgical video prepared by the same expert faculty on knee and shoulder arthroscopic practice models. In this video, the same aspects of knee and shoulder arthroscopy that were taught to

\section{TABLE II}

Diagnostic shoulder arthroscopy checklist for performed tasks sorted sequentially

\author{
Scope introduction \\ Mark anatomic landmarks (acromion, coracoid, clavicle, \\ scapular spine) $\left(T_{10}\right)$ \\ Insert scope into glenohumeral joint $\left(\mathrm{T}_{11}\right)$ \\ Glenohumeral arthroscopy \\ Probe glenoid and humeral cartilage $\left(\mathrm{T}_{12}\right)$ \\ Probe superior and anterior labrum $\left(\mathrm{T}_{13}\right)$ \\ Probe posterior labrum ( $\left.T_{14}\right)$ \\ Pass probe superior to biceps, bring it into joint $\left(T_{15}\right)$ \\ T: Task.
}

group E1 were demonstrated and explained audiovisually. Group E3 only read the surgical techniques explaining the abovementioned aspects of both types of arthroscopy. Group E4 watched the same surgical video used in group E2 after reading the same surgical technique used for group E3 students. Group E5 was the control group, and students in this group did not receive any pre-training.

After completion of the pre-training, each student was asked to perform an arthroscopy practice task on the same practice models used for pre-training with a standard $30^{\circ}$ arthroscope (Stryker Arthroscope $4.0 \mathrm{~mm}$, Michigan, USA) and arthroscopy camera display system (Stryker, Michigan, USA). Students received a checklist containing the tasks to be performed, and they were asked to complete the checklist within five minutes (Tables I, II). ${ }^{[11]}$ The number of tasks fully completed in five minutes was recorded in each group and for each student (Tables III, IV).

\section{Statistical analyses}

The rate of fully completed tasks for each group was calculated, and the differences among groups were statistically analyzed. Furthermore, the number of students who completed all the tasks in the given time in each group was statistically compared across groups. Normality tests were performed for the completion times of the tasks given in each training group.

Statistical analyses were performed using the IBM SPSS software version 24.0 (IBM Corp., Armonk, NY, USA). The variables were investigated using visual (histograms, probability plots) and analytical (Kolmogorov-Smirnov/Shapiro-Wilk tests) methods to determine whether they were normally distributed. Descriptive analyses were presented 


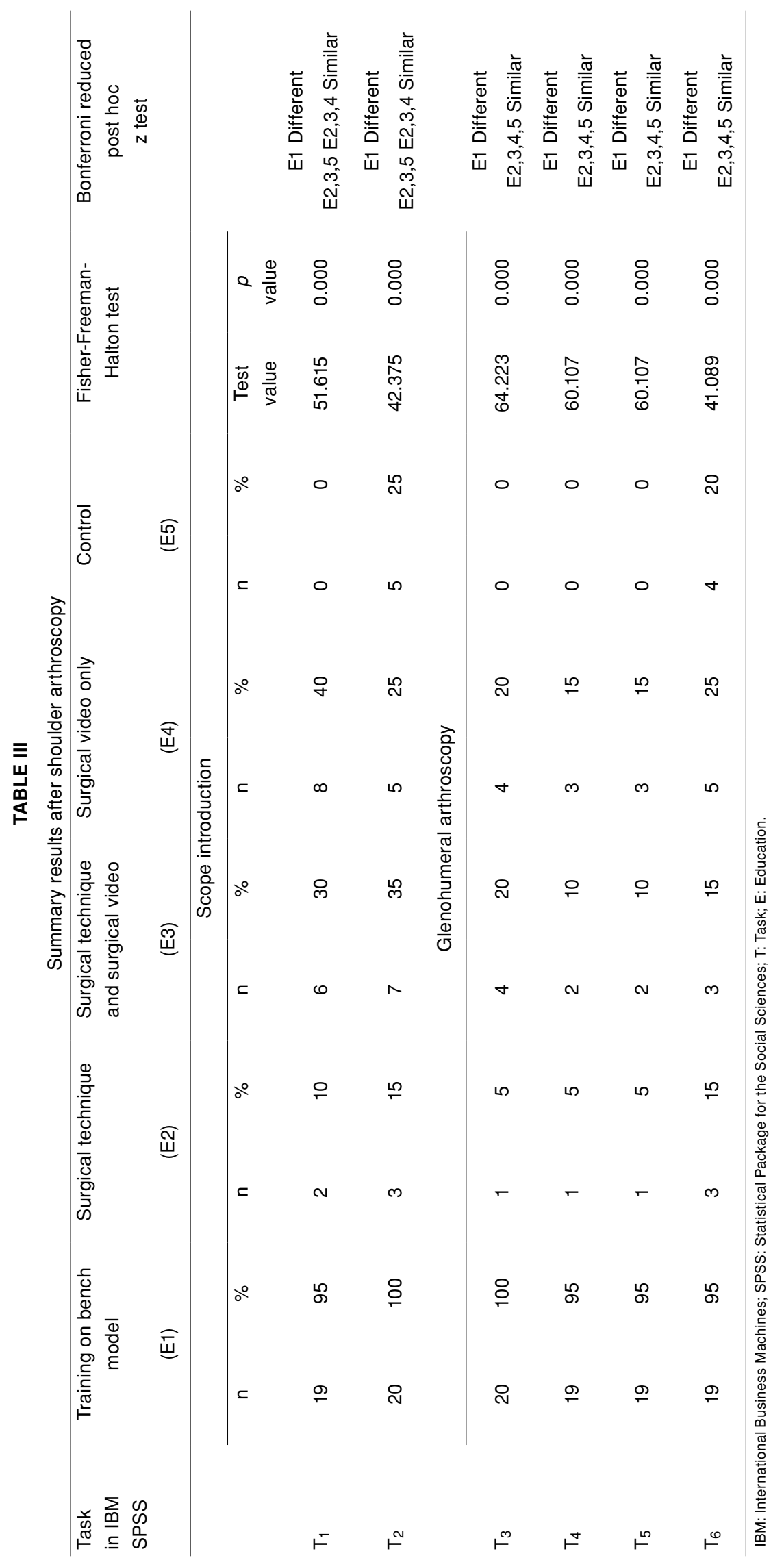




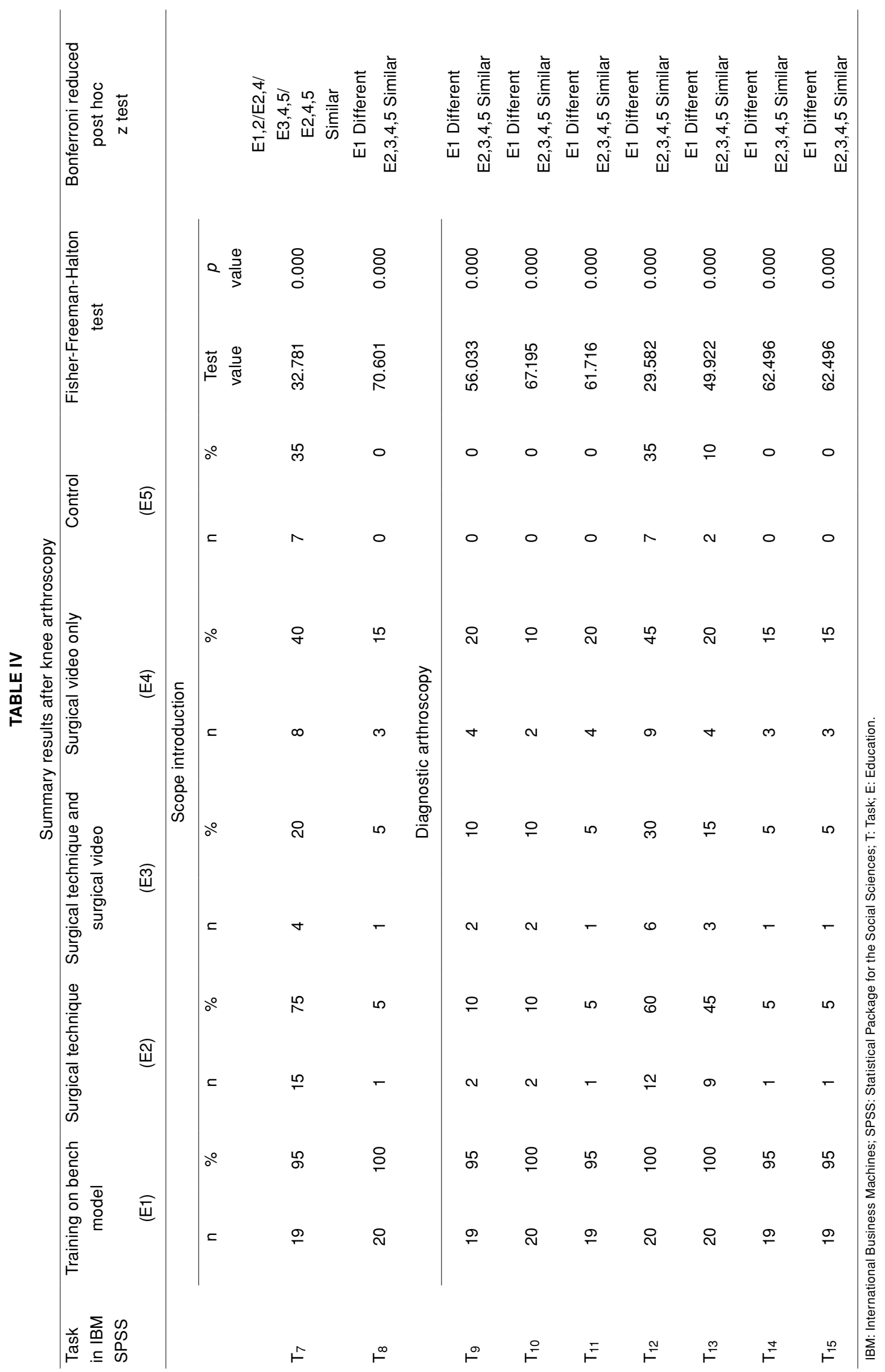


using mean, standard error mean, standard deviation, variance, medians, minimum, and maximum for nonnormally distributed and ordinal variables. According to the results of the Kolmogorov-Smirnov tests, only the results of group E1 had normal distribution. Therefore, the Kruskal-Wallis test was conducted to compare the training models. The Fisher-Freeman-Halton test, an extension of the Fisher's exact test, was applied for contingency tables that were not $2 \times 2 .{ }^{[12]} \mathrm{A} p$ value of less than 0.05 was considered to indicate a statistically significant result. Significantly different groups were identified by Bonferroni's corrected post hoc $\mathrm{z}$ test.

\section{RESULTS}

Regarding shoulder arthroscopy tasks, the percentage of tasks successfully completed was $96.6 \%$ (95\%-100\%) in group E1, whereas it was 9.6\% (5-15\%) in group E2, $20 \%(10 \%-35 \%)$ in group E3, $23.3 \%$ $(15 \%-40 \%)$ in group E4, and 7.5\% (0\%-20\%) in group E5. The detailed rates of success for each task in each group were summarized in Table III. Additionally, the rate of successful achievement for each task was statistically significantly different for only group E1 compared with other groups $(\mathrm{p}<0.001)$. The differences for each task were statistically significantly similar for groups E2, E3, E4, and E5 ( $>00.05)$.

The mean time for completion of the tasks in the shoulder arthroscopy model for group E1 was 203.1 seconds (sec) (64-300 sec). Only two students could not complete all the tasks in the given time. In group E2, only one student completed all the tasks in 280 seconds. Only two students in group E3 completed all the tasks in a mean time of 202.5 seconds (195 sec and $210 \mathrm{sec}$, respectively). Three students in group E4 completed all the tasks in a mean time of 198 seconds (146 sec, $208 \mathrm{sec}$, and $240 \mathrm{sec}$, respectively). There were no students in group E5 who successfully completed all the tasks. The difference between these groups was statistically significant for only group E1 compared with other groups (Table V).

TABLE V

Summary results of descriptive statistical studies for shoulder and knee arthroscopy

\begin{tabular}{cccr}
\hline & \multicolumn{3}{c}{ Kruskal-Wallis test } \\
\hline Kruskal-Wallis test & Median & Mean Rank & z score \\
\hline E1 & 208.5 & 17.1 & 5.76 \\
E2 & 300 & 57.2 & 1.73 \\
E3 & 300 & 55.3 & 1.12 \\
E4 & 300 & 62.5 & 0.85 \\
E5 & 300 & 50.5 & 2.07 \\
\hline
\end{tabular}

$H=33.90 ; d g=4 ; p=0.000$.

Descriptive statistics shoulder arthroscopy

\begin{tabular}{cccccccc}
\hline $\begin{array}{c}\text { Education } \\
\text { models }\end{array}$ & Mean & SE mean & $\begin{array}{c}\text { Standard } \\
\text { deviation }\end{array}$ & Variance & Minimum & Median & Maximum \\
\hline E1 & 203.1 & 14.7 & 65.6 & 4309.5 & 64.0 & 208.5 & 300 \\
E2 & 299.00 & 1.00 & 4.47 & 20.00 & 280.00 & 300 & 300 \\
E3 & 290.25 & 6.73 & 30.11 & 906.51 & 195.00 & 300 & 300 \\
E4 & 284.70 & 9.05 & 40.46 & 1636.75 & 146.00 & 300 & 300 \\
E5 & 300.00 & 0.000000 & 0.000000 & 0.000000 & 300.00 & 300
\end{tabular}

Descriptive statistics knee arthroscopy

\begin{tabular}{cccccccc}
\hline $\begin{array}{c}\text { Education } \\
\text { models }\end{array}$ & Mean & SE mean & $\begin{array}{c}\text { Standard } \\
\text { deviation }\end{array}$ & Variance & Minimum & Median & Maximum \\
\hline E1 & 145.40 & 15.6 & 69.77 & 4867.93 & 50.0 & 134 & 300 \\
E2 & 300.00 & 0.000000 & 0.000000 & 0.000000 & 300.00 & 300 & 300 \\
E3 & 296.45 & 3.55 & 15.87 & 252.05 & 229.00 & 300 & 300 \\
E4 & 299.50 & 0.50 & 2.23 & 5.00 & 290.00 & 300 & 300 \\
E5 & 300.00 & 0.000000 & 0.000000 & 0.000000 & 300.00 & 300 & 300 \\
\hline
\end{tabular}

SE: Standard error; E: Education. 
Regarding knee arthroscopy tasks, the number and rate of students who completed each task successfully in each group were summarized in Table IV. The mean percentage of tasks successfully completed in group E1 was $97.2 \%$ (95\%-100\%), whereas it was $24.4 \%$ (5\%-60\%) in group E2, $11.6 \%(5 \%-30 \%)$ in group E3, $22.2 \%$ $(10 \%-45 \%)$ in group E4, and $8.8 \%(0 \%-35 \%)$ in group E5. Additionally, the rate of successful achievement for the task E1 was statistically significantly similar for the following sets of groups: E1 and E2; E2 and E4; E2, E4, and E5; and E3, E4, and E5. For the other tasks, the rate of successful achievement was statistically significantly different for only group E1 compared with other groups $(\mathrm{p}<0.001)$, and it was statistically significantly similar for groups E2, E3, E4, and E5 $(\mathrm{p}>0.05)$.

The mean time for completion of the tasks in the knee arthroscopy model for group E1 was 145.4 seconds ( $60 \mathrm{sec}-300 \mathrm{sec}$ ). Only one student could not complete all the tasks in the given time. In groups E2, E3, and E4, only one student completed all the tasks in $290 \mathrm{sec}, 229 \mathrm{sec}$, and $290 \mathrm{sec}$, respectively. There was no student in group E5 who completed all the tasks. The only significant difference among these groups was that for group E1 compared with other groups (Table V).

A comparison of the genders of the students who completed all the tasks successfully in each group for both arthroscopy models revealed no statistically significant difference $(\mathrm{p}>0.05)$.

\section{DISCUSSION}

The most important finding revealed in this study is that basic arthroscopic skills can be acquired successfully by simulation training compared with didactic training models of lectures, reading and audio-visual supports. Furthermore, when the success rates of trainees in didactic training groups were compared with the control group who did not receive any pre-training, it was obviously seen that this type of training models do not provide significant acquisition of any surgical skill in contrast to simulator training.

The difference for success rates between different pre-training groups may be explained by the learning pyramid figure for acquisition and retention of knowledge described by Edgar Dale and developed by National Training Laboratories for Applied Behavioral Sciences Bethel, Maine. ${ }^{[13]}$ According to this pyramid, rate of learning increases when demonstrations, group discussions, practice by doing and teaching (immediate use of learning) are added to standard training models of lectures and reading with audio-visual support. In this pyramid, these didactic learning techniques are described as the least effective training models in order. Higher and successful skill gain in simulator group may be explained by the chance for practice with realistic depth perception and psychomotor sensation. Kopta's description of acquisition of psychomotor skills may clarify the reasons for differing rates of skills achievement between pre-training groups. ${ }^{[14]}$ Kopta describes acquisition of psychomotor skills in cognitive, integrative and autonomous phases. During the second integrative phase, the knowledge gained in the cognitive phase with didactic learning is transformed into motor behavior, which is essential for a successful autonomous phase. However, didactic learning models of lecturing, reading and audiovisual supports are effective only in cognitive phase and do not affect the autonomous behavioral phase (which is arthroscopic manipulation skill in our study) without the phase of integration. The simulator training seems to play an affective role on integrative phase of training here.

Innate attainments, which are shown to be present among surgeons, ${ }^{[2]}$ may play a role in acquisition of dexterity in surgical skills training. This inherited tendency may create variations in learning curves, which can be an explanation for successful completion of tasks for students trained by reading and/or video lecturing. Objective technical dexterity gained by interests in manual labors as model making or video gaming may also cause such a difference between individuals. Another explanation for these variations may be the difference between the time spent for each student to feel themselves ready for success.

In the literature, there are many studies underlining the effect of different learning models for arthroscopic skills practice. In their study reporting the results of a survey answered by orthopedic residents, residency program directors and orthopedic sports medicine attending physicians, Koehler et al. ${ }^{[15]}$ underlined that traditional methods consisting assisting or performing arthroscopic surgery, observation in the $\mathrm{OR}$ and reading published materials are still the most common arthroscopic training resources. It was reported in the same study that most of the participants of the survey indicated practice with cadaveric specimens as the most effective method of training, followed by simulation training with benchtop artificial models, which was reported to be more effective than OR observations. Martin et al. ${ }^{[16]}$ also demonstrated strong correlation between performance of basic arthroscopic tasks in a simulator model and cadaveric model. These reports are parallel with our 
objective findings, where participants training with bench-top simulation models had better results of completion of tasks within shorter time.

In our study, we used a number of tasks completed in a given time. Our post-training outcomes included times to completion of the checklist for all students in each group. Cannon et al. ${ }^{[9]}$ emphasized that time should be used as an important criterion for measuring performance in future studies. Slade Shantz et al. ${ }^{[17]}$ demonstrated that time to task completion is the most uniform metric for skill comparison. Moreover, Rebolledo et al. $^{[18]}$ found that a simulator-trained group had improved time to completion of diagnostic shoulder arthroscopy, whereas there was no difference between groups for knee arthroscopy tasks. In this study, it was shown that the hands-on simulator group performed better and completed the tasks in both arthroscopy models in shorter time than the other groups. However, we did not compare time of completion in shoulder and knee arthroscopy tasks, which prevented us from commenting on learning durations for different joint models.

It has been emphasized that a valid, global rating scale is required to standardize outcome measures in arthroscopic training studies. ${ }^{[7,19]}$ In our work, we used a checklist that Nwachukwu et al. ${ }^{[1]}$ created for the purpose of standardization. In addition, laboratorybased simulator training systems are not available in many centers in developing countries. In such contexts, training tools should be cheap and easy to access to safeguard effective training. Seymour et al. ${ }^{[20]}$ highlighted the cost of surgical training to optimize medical training. For this reason, we established a simple arthroscopic simulator from an obsolete arthroscopy tower. We have shown that the old, idle arthroscopy towers can be used in resident arthroscopic skill development training, ${ }^{[21]}$ particularly in clinics where access to computerized simulator systems is difficult.

In the literature, there are many studies reporting successful acquisition of arthroscopic skills with simulator training. ${ }^{[18,22-25]}$ However, there is controversy about retaining these skills and their transfer to operation room. Howells et al. ${ }^{[24]}$ demonstrated a loss of improvement gained by simulator training when such skill is not used for a period of six months. However, this skill was reported as an arthroscopic Bankart suture, which probably necessitates simulator training for a longer time when compared with diagnostic arthroscopic training. Performing complex surgical interventions with a high level of performance may require both longer training times and repetition of training sessions. Atesok et al. ${ }^{[26]}$ also underlined that evidence of simulation-based retention of skills in orthopedic surgery is limited and suggested repeated practice of the tasks on simulator. On the other hand, Martin et al ${ }^{[16]}$ revealed a high level retention of arthroscopic tasks management due to high performance of the same tasks in a cadaveric model. Jackson et al. ${ }^{[22]}$ indicated protection of the skill level acquired on knee arthroscopy simulator even after a six-month interruption in task performance. They showed that there is a learning curve where further improvements are gained by differing episodes of simulation training. They highlighted the presence of task-specific and surgical-group-specific factors that affect the retention of arthroscopic skills. A randomized blinded study performed by Cannon et al. ${ }^{[9]}$ demonstrated transfer of training skills to operation theatre and suggested incorporation of surgical simulation training to residency programs. In light of such findings associated with our results, we think that simulation training for acquisition of diagnostic arthroscopic skills is an effective method. It may require performing more complex procedures on simulators for gaining higher skill levels to perform complex issues such as meniscus, labrum and rotator cuff debridement or suturation and to retain these skills to transfer them to the OR.

Our study has some limitations. We showed that the simulator group had better performance both in terms of time and rate of task completion. However, this finding is only relevant to the effectiveness of simulator training in resident training. We did not evaluate the transfer validity of arthroscopy skills acquired through simulation to the OR. In addition, this study included only single-center outcomes. Therefore, further multicenter studies should be planned by incorporating orthopedic associations.

In conclusion, a basic arthroscopic bench-top simulator can be a low-cost and effective training method to increase arthroscopic skill levels and decrease the duration of arthroscopy in resident training compared with traditional methods, particularly in developing countries.

\section{Acknowledgements}

We thank Ellen Shuman from Edanz Group (www.edanzediting.com/ac) for editing a draft of this manuscript.

\section{Declaration of conflicting interests}

The authors declared no conflicts of interest with respect to the authorship and/or publication of this article.

\section{Funding}

The authors received no financial support for the research and/or authorship of this article. 


\section{REFERENCES}

1. Satava RM, Gallagher AG, Pellegrini CA. Surgical competence and surgical proficiency: definitions, taxonomy, and metrics. J Am Coll Surg 2003;196:933-7.

2. Alvand A, Auplish S, Gill H, Rees J. Innate arthroscopic skills in medical students and variation in learning curves. J Bone Joint Surg Am 2011;93:115.

3. Bridges M, Diamond DL. The financial impact of teaching surgical residents in the operating room. Am J Surg 1999;177:28-32.

4. Hawasli A, Featherstone R, Lloyd L, Vorhees M. Laparoscopic training in residency program. J Laparoendosc Surg 1996;6:171-4.

5. Aggarwal R, Moorthy K, Darzi A. Laparoscopic skills training and assessment. Br J Surg 2004;91:1549-58.

6. Rosenthal R, Gantert WA, Scheidegger D, Oertli D. Can skills assessment on a virtual reality trainer predict a surgical trainee's talent in laparoscopic surgery? Surg Endosc 2006;20:1286-90.

7. Aïm F, Lonjon G, Hannouche D, Nizard R. Effectiveness of Virtual Reality Training in Orthopaedic Surgery. Arthroscopy 2016;32:224-32.

8. Modi CS, Morris G, Mukherjee R. Computer-simulation training for knee and shoulder arthroscopic surgery. Arthroscopy 2010;26:832-40.

9. Cannon WD, Garrett WE Jr, Hunter RE, Sweeney HJ, Eckhoff DG, Nicandri GT, et al. Improving residency training in arthroscopic knee surgery with use of a virtualreality simulator. A randomized blinded study. J Bone Joint Surg [Am] 2014;96:1798-806.

10. Scott DJ, Bergen PC, Rege RV, Laycock R, Tesfay ST, Valentine RJ, et al. Laparoscopic training on bench models: better and more cost effective than operating room experience? J Am Coll Surg 2000;191:272-83.

11. Nwachukwu B, Gaudiani M, Hammann-Scala J, Ranawat A. A Checklist Intervention to Assess Resident Diagnostic Knee and Shoulder Arthroscopic Efficiency. J Surg Educ 2017;74:9-15.

12. Lydersen S, Pradhan V, Senchaudhuri P, Laake P. Choice of test for association in small sample unordered $\mathrm{r} \times \mathrm{c}$ tables. Stat Med 2007;26:4328-43.

13. Masters K. Edgar Dale's Pyramid of Learning in medical education: a literature review. Med Teach 2013;35:1584-93.

14. Kopta JA. The development of motor skills in orthopaedic education. Clin Orthop Relat Res 1971;75:80-5.

15. Koehler R, John T, Lawler J, Moorman C, Nicandri G. Arthroscopic training resources in orthopedic resident education. J Knee Surg 2015;28:67-74.

16. Martin KD, Belmont PJ, Schoenfeld AJ, Todd M, Cameron KL, Owens BD. Arthroscopic basic task performance in shoulder simulator model correlates with similar task performance in cadavers. J Bone Joint Surg Am 2011;93:1271-5.

17. Slade Shantz JA, Leiter JR, Gottschalk T, MacDonald PB. The internal validity of arthroscopic simulators and their effectiveness in arthroscopic education. Knee Surg Sports Traumatol Arthrosc 2014;22:33-40.

18. Rebolledo BJ, Hammann-Scala J, Leali A, Ranawat AS. Arthroscopy skills development with a surgical simulator: a comparative study in orthopaedic surgery residents. Am J Sports Med 2015;43:1526-9.

19. Howells NR, Gill HS, Carr AJ, Price AJ, Rees JL. Transferring simulated arthroscopic skills to the operating theatre: a randomised blinded study. J Bone Joint Surg [Br] 2008;90:494-9.

20. Seymour NE, Gallagher AG, Roman SA, O'Brien MK, Bansal VK, Andersen DK, et al. Virtual reality training improves operating room performance: results of a randomized, double-blinded study. Ann Surg 2002;236:458-63.

21. Atik OŞ. Do we surgeons perform surgery only? Eklem Hastalik Cerrahisi 2016;27:123-4.

22. Jackson WF, Khan T, Alvand A, Al-Ali S, Gill HS, Price AJ, et al. Learning and retaining simulated arthroscopic meniscal repair skills. J Bone Joint Surg [Am] 2012;94:e132.

23. Colaço HB, Tennent D. Simulation in shoulder surgery. Shoulder Elbow 2016;8:287-96.

24. Howells NR, Auplish S, Hand GC, Gill HS, Carr AJ, Rees JL. Retention of arthroscopic shoulder skills learned with use of a simulator. Demonstration of a learning curve and loss of performance level after a time delay. J Bone Joint Surg [Am] 2009;91:1207-13.

25. Martin KD, Patterson DP, Cameron KL. Arthroscopic Training Courses Improve Trainee Arthroscopy Skills: A Simulation-Based Prospective Trial. Arthroscopy 2016;32:2228-32.

26. Atesok K, Satava RM, Van Heest A, Hogan MV, Pedowitz RA, Fu FH, et al. Retention of Skills After Simulation-based Training in Orthopaedic Surgery. J Am Acad Orthop Surg 2016;24:505-14. 